\title{
Board Characteristics, Audit Committee Characteristics, and Audit Fees: Evidence from Jordan
}

\author{
Hassan Yahia Kikhia ${ }^{1}$ \\ ${ }^{1}$ School of Accounting and Finance, Zhongnan University of Economics and Law, Wuhan, China \\ Correspondence: Hassan Yahia Kikhia, Doctoral Student, School of Accounting and Finance, Zhongnan \\ University of Economics and Law, Wuhan, China. E-mail: hassankh.2011@ hotmail.com
}

Received: October 11, 2014

Accepted: October 29, 2014

Online Published: November 25, 2014

doi:10.5539/ibr.v7n12p98

URL: http://dx.doi.org/10.5539/ibr.v7n12p98

\begin{abstract}
The current study aims to examine the influence of characteristics of board of director (board independence, expertise, and size) and characteristics of audit committee (independence, expertise, and meeting frequency) on audit fees in Jordan, by using the sample of 112 non-financial companies which listed on Amman Stock Exchange (ASE) that meet the selection criteria and have the relevant financial data obtainable from 2010 until 2012 (336 observation). The results reveal significant and positive relationship between external audit fees and board independence, expertise and size, and these findings support "demand side" arguments which suggest that board directors having independence, financial expertise and higher number of board size support the demand for high audit quality. The second finding reveals that both audit committee expertise and the number of audit committee meeting did not show any significant relationship with audit fees. On the contrary, audit committee independence is significantly positively associated with the level of audit fees, and this result goes in the same line with the study hypothesis. This study might alert the Jordanian regulators about the circumstances that the Jordanian companies' code is only just ticking the box. Therefore, the regulators must be more careful to make certain that this code is being applicable in terms of substance and form. Furthermore, this study also has potential implications for relevant countries which have similarities in legislative framework and government oversight.
\end{abstract}

Keywords: audit fees, board characteristics, audit committee characteristics, Jordan

\section{Introduction}

In the past few years increasing at attention has been given to the auditing services providing by the accounting profession. One area of concern has been the rapidly rising costs of the external audit. With this rapid rise in audit fees some researchers are openly questioning the value for money of an audit. The first motivation that leads to critical academic research into the determinants of the level of audit fees was the US market, where significant effort took place with outstanding emphasis on fee determinants. Whereas at the same time, spreading to a consideration of other research questions applying the generally accepted auditing fee model. However, according to previous studies, the determinants of audit fees can be generally classified into three major groups: Client characteristics, auditor characteristics and corporate governance characteristics (Simunic, 1980; Hay et al,. 2008; Griffin et al., 2008; Wu, 2012; Rustam et al., 2013). Numerous studies have been managed on both the auditee and auditors characteristics and their relationship with audit fees, but few studies have addressed the issue of the relationship between corporate governance and audit fees.

However, for corporate governance, there are two arguments, at least, that define the relationship connecting corporate governance and audit fees. The first is informed by substitution theory and the other one by signalling theory, and both lead to different results. Substitution theory proposes that the more ideal the internal structure of the firm's corporate governance, and thus the lower the agency costs, the less risks the audit firm and auditor will face and accordingly the less the audit fee that will be charged. In other words, auditing is considered as a form of external governance for which effective internal corporate governance may substitute to some extent. However, signalling theory argues that managers signal high-level corporate governance to external shareholders by inviting a more rigorous external auditor to audit the firm in order to give a signal to the external shareholders about the quality of company's corporate governance, which inevitably leads to higher audit fees. However, it does not seem unreasonable to suggest that the question of which theory better explains corporate practice is still 
unanswered despite of the varied empirical evidence reported to date and these conflicting views justify doing much more research in this issue. Additionally, there are many variables that constitute an index for measuring corporate governance in an organization. The features of corporate governance that are examined in this study are: Characteristics of board of directors (board independence, expertise, and size) and characteristics of audit committee (audit committee independence, expertise, and meeting frequency).

Board characteristics, since one of the board's responsibilities is to monitor the financial reporting and audit processes, this can be done in two methods: formal and informal. Formally, the board is involved with choosing the external auditor together with management and if present, the audit committee. This means that the board has influence in the audit process and the suggested audit fee. Informally, the presence of the board can be a signal for auditors that the quality of the audit is expected to be quite high. This can induce extra effort for auditors performing the audit (Carcello et al., 2002). Furthermore in the recent years, new Jordanian requirements have increased the responsibilities of board of directors in general and legal responsibility in particular. Therefore, the impact of board of directors on financial and audit process has been increased. Moreover, the association between audit fees and audit committee characteristics is unclear and not well understood in spite of numerous researches which have been done in this area. In the meantime, there are different opinions suggesting that the audit committee effectiveness could result in either decrease or an increase. If an audit committee improves the internal control strength, a reduced a level of audit fess would be predictable. On the other hand, if an audit committee pursues to improve the quality of audit service, the influence could be an increase in the level of audit fees. Accordingly, these conflicting views were the motivation to the researcher to select the audit committee characteristics as potential determinant for audit fees in this research.

Moreover, several studies have been focused on the market for audit profession and services in developed countries, but few research have been conducted on developing countries in general and Arabic world in particular. Thus, the current study extends previous studies by presenting a new evidence about the audit market in Jordan, where there are difficulties and problems facing the audit profession involve; lack of independence while performing the audit services because of relying on personal relationship, poor quality of audit evidence, poor auditor qualification due to the lack of continuous education (World Bank, 2004). Additionally, there is a gap between accounting profession and education due to the lack of adequate academic research publications, and this gap justifies doing more studies in this issue. Furthermore, the study has potential implications for relevant countries which have similarities in legislative framework and government oversight.

\section{Literature Review and Hypotheses Development}

\subsection{Board Characteristics}

Previous Studies indicated that audit fees have relationship with the quality of corporate governance and they argued that external auditors consider corporate governance as an internal control mechanism, which influences the extent and nature of audit testing (O'Sullivan, 2000; Carcello et al., 2002; Hay \& Knechel, 2004; Lajmi and Gana, 2011). In this article, the characteristics of board of directors that have been studied include board independence, expertise and board size.

\subsubsection{Audit Fees and Board Independence}

Board independence refers to the state in which all or a majority of the members of a board of directors do not have a relationship with the company except as directors. Hay and Knechel (2004) discus that the board independence will support the audit function because the independent board members seek to decrease their responsibilities toward questionable financial reporting decisions made by management. In Jordan, Al-Sharef (2008) investigated the relationship between corporate governance and effectiveness of internal auditing by using a sample of (56) internal auditors within the industrial sector. The study used questionnaire to collect the data. The result of this study was generally consistent with the literature that indicated positive association between corporate governance dimensions (namely board independence) and the effectiveness of audit function. On the other hand, O'Sullivan (1997) found that firms with a higher proportion of independent directors are more likely to seek for more supervision responsibilities as opposed to boards with a lower proportion of independent directors. Greater board independence with financial proficiency is related to more transparent disclosures on the performance of companies which might require more audit effort than the standard amount of effort being expended, which result in an increase in audit quality and therefor audit fees. According to the previous studies which suggest that companies with greater board independence will seek for more comprehensive audit, this study will propose the following hypothesis:

H1: There is a positive relationship between board independence and external audit fees. 


\subsubsection{Board Expertise and Audit Fees}

To perform the financial reporting process, the board members should have accounting and financial experience in order to produce high financial reporting. Robertson and Lanfranconi (2002) indicated that the breakdown of Enron and WorldCom was because of the lack of experience of their board members. Specifically, in the Enron situation, the board members did not understand and recognize its complex financial structures that used special purpose entities. On other hand, in the WorldCom situation, the board members did not have basic knowledge about accounting principles. Moreover, they were not aware of expenditure being capitalized instead of expensed. To conduct specified responsibilities and duties, the board members should contain a diverse collection of skills. In addition, having board members with poor and lack experience and knowledge threatens the company performance due to their disability to deal with issues affecting the company's business. Therefore, this study expects that the members of boards of directors who have more experience are more likely to seek for higher quality audit service, resulting in higher audit fees. The discussion above leads to the following hypothesis:

$\mathrm{H} 2$ : There is a positive relationship between board expertise and external audit fees.

\subsubsection{Board Size and Audit Fees}

Board size is observed as an important component of board characteristics that may affect audit fees. The long-term objectives and direction of organizations are the responsibility of boards of directors. A study has been done by Beasley (1996) pointed out that the board size has material influence on the quality of corporate governance and significantly affects the likelihood of financial statement frauds. Therefore, as the size of the board of directors increases, the possibility of fraudulent financial statement will also increase. Further, high board size inclines to contain less significant discussion due to many directors are involved in the discussion, making it both time consuming and difficult to achieve cohesiveness. Additionally, too many people inside the same geographical position cannot work together effectually. However, for the current study, as mentioned previously, the researcher is more inclined to support "demand side" view which suggests that the higher board members is more likely to involve less significant discussion due to large directors are involved in the discussion led to a problem of coordination, thus the company could adopt approach of demanding high-quality, sufficient audit coverage to make a positive impression in the investors' minds about the quality of financial reporting and audit, this leading to higher audit fees. This discussion drives to the following hypothesis:

H3: There is a positive relationship between the board size and external audit fees

\subsection{Audit Committee Characteristics}

The audit committee helps to assure independence. The audit committee is comprised of directors, not managers, and their job is to appoint, retain, oversee, evaluate and terminate the audit firm. Previous studies argue that the key of audit committee characteristics, rather than the mere existence of an audit committee, critically influence the audit committee's capability to effectually perform its duties (Abbott et al., 2003). Consistent with previous research, this study revolves around audit committee independence, experience and the audit committee meeting frequency.

\subsubsection{Audit Committee Independence and Audit Fees}

Numerous researches propose that independence of audit committees are less probable to be connected with fraudulent financial statement (Abbott et al., 2000; Abbott et al., 2004) and more likely to be connected with lower earnings management (Xie et al., 2003) and a lower incidence of earnings restatement (Agrawal \& Chadha, 2005). The independence of audit committee is expected to provide unbiased assessment and judgment and to be able to monitor management effectively. In Jordan Hamdan and Mushtaha (2011) studied the association between the characteristics of the audit committee of the industrial Jordanian companies which listed on ASE and the likelihood of the company getting an audit clean report. The results of their study pointed out that the independence of audit committee and the number of meetings had no impact on the opinion of the external auditors. However, related to the relationship between external audit fees and audit committee characteristics, the researcher did not find any previous study which sort out such relationship in Jordan. In conclusion, independent audit committee members may suggest demanding expended audit scope while the review of the audit program so as to preserve reputational capital and to avoid being related with financial misstatement (Abbott et al., 2003). For the current study, the researcher supports the opinion which proposes that independent audit committee will demand doing additional audit procedures and supports the auditor while negotiations with the managements, which in turn results in higher level of audit fees. Therefore, the current hypothesis will be as follow:

H4: There is a positive relationship between audit committee independence and the level of audit fees. 


\subsubsection{Audit Committee Expertise and Audit Fees}

Financial knowledge and expertise enhance audit committees effectiveness. In general, the expertise of audit committee plays an important role in audit function. However, it's worth pointing out that in Jordan the study of Al-Farah (2001) aimed at measuring how active are Jordanian audit committees from the perspective of internal and external auditors. It also tried to know the significant features that help to consolidate efficiency of such committees from the opinion of members of the audit committees of the Jordanian companies. The most important findings of the study were that the audit committees were active from the perspective of internal auditors, but never from the perspective of the external auditors. Some of the features that consolidate the role of audit committees are the financial and accounting knowledge of one member of the audit committee. On other hand, Lisic, et al. (2011) tried to study the relationship between incidence of restatements that is moderated by CEO power and audit committee financial expertise. The results of this study pointed out that the financial expertise of the audit committee is negatively related to incidence of restatements when the proxy for CEO power is low. Consequently, for the current study, the researcher believes that the audit committee which contains members with financial and accounting knowledge is more likely to support external auditors while discussing auditing issues with the management and such committee with this expertise is more likely to understand the risk that the external auditor faces, thus leading to propose the following hypothesis:

H5: There is a positive relationship between audit committee expertise and the level of audit fees.

\subsubsection{Audit Committee Meeting Frequency and Audit Fees}

The Audit committee frequency meeting is generally used in prior studies to define the diligence of audit committee members. However, according to literature review the existence of a committee doesn't mean that the committee will be effective. The attention has been shifted to the activities of audit committee in general and the frequency of committee meetings in particular (Jenny \& lois, 2007; Feng et al., 2012). In the same manner, recent research provide evidence about the importance of audit committee frequency meeting. For instance, Beasley et al. (2000) pointed out that the audit committees which met less were more likely to fraud than that committee which met frequently. Moreover, Abbott et al. (2003) found that companies whose audit committee members met more than four times per year are less expected to obtain and have restated their audited financial statements. In Jordan, however, there is no study which has ever directly studied the association between the level of audit fees and audit committee meeting frequency. Nevertheless, the results of prior research support the viewpoint that the audit committee which meet frequently are more knowledgeable of current audit issues and more effectively and therefore more likely to support the auditor and understand his or her issues, thus lead us to expect positive association between frequently meeting and the level of audit fees.

H6: There is a positive relationship between audit committee meeting frequency and the level of audit fees.

\section{Auditing Profession and Corporate Governance in Jordan}

Since the independence of Jordan in 1946, the audit profession has increased meaningfully in size. At present, there are about 300 audit firms in Jordan, ranging from a majority of very small audit firms to a minority of firms who are significantly larger and deal with much larger clients, including multinationals operating in Jordan (Abdullatif, 2013). Numerous Jordanian audit firms have some kind of connection with an international audit firms, including the Big Four. Currently, many of these Jordanian firms have managed a full membership in their international audit firm groups. This necessitates the Jordanian firm to follow the audit methodology and detailed programs of its international audit firm (insofar as required by the international firm), and to be inspected by that firm for quality control (Abdullatif \& Al-Khadash, 2010).

Closely-held firms are the main audit clients in Jordan, particularly family-dominated. There is a limited separation between management and ownership, and the most senior positions in management are given to the biggest shareholders along with their relationships. Furthermore, whilst Jordanian public shareholding companies are required to establish audit committees, the efficiency of these committees might be restricted under such a governance system due to the fact that nonexecutive and executive members of boards of directors are supposed to have strong relationships (Abdullatif, 2013). At the same time, audit committee members do not have strong financial expertise. As stated by Abdullatif \& Al-Khadash (2010) this type of corporate governance system, where leading executive managers (themselves major shareholders) are not answerable to minor shareholders, is likely to affect the nature of the purpose of the audit function and reduce its quality (and hence lower audit fees) giving the lower agency costs involved.

Khoury (2003) proposes that corporate governance in Jordan can be categorized into six aspects: A capital market, a legislative framework and government oversight, disclosure and accounting standards, transparency in 
privatization, supervision of the board of directors and preservation of property rights, and protection of minority rights. These six aspects are broadly stated in the Companies Law of 1997 and its mandates of 2002, and some in the Securities Law of 2002. However, the first code of Jordanian corporate governance has been published in 2005 by the Amman Stock Exchange. This code contains five chapters which involved identification of key terminology; information about the general meeting of shareholders; some guidelines for financial disclosures alongside with a conceptual framework for auditing and accountability; and summary of board responsibilities and board's structure.

\section{Methodology}

\subsection{Sample and Data Collection}

The analysis is based on collection the data from the 2010 until 2012 financial statements of companies which listed on (ASE). This goes back to the difficulty in providing online annual reports of some companies before 2010. Besides that, lots of companies have not disclosed their annual reports for 2013 while performing this research. Taking into consideration the research requirements and the comparability of data, I selected the sample along with the following standards: Firstly, excluding listed companies that have not disclosed annual external audit fee in their annual reports; Secondly, the company is listed on ASE during the study period (2010, 2011, and 2012); Thirdly, excluding listed companies that stopped trading during the study period; Fourthly, bearing in mind the variance between the financial listed companies and listed companies in other sectors whether in term of the nature of business or the applicable accounting system could have an effect on the audit fees, so the sample does not comprise financial companies; Finally, if any required indicator is not available in the disclosure of company, this company is excluded from the sample.

Eventually, 121 companies (out of 130 firms in total) meet the selection standards and have the appropriate financial data obtainable. The sample is considered suitable because financial companies excluded from this research have extra regulatory environments and the treatment of items in their financial statements is dissimilar, making the determination of audit fees different from the non-financial companies. In Table (1) the sample description is specified. From this table, it can be seen that the highest contributing sector is the industrial sector with (66) companies and the services sector contributes (55) companies, for the finance sector and as we indicated above, the sample doesn't include financial companies. The expected company-year observations total to 363 .

Table 1. Sample description

\begin{tabular}{lccccc}
\hline Sector & Population & year observations $(* 3)$ & Sample & Sample(*3) & Percentage \\
\hline Industrial & 72 & 216 & 66 & 198 & $54.54 \%$ \\
Services & 58 & 174 & 55 & 165 & $45.46 \%$ \\
Finance & 112 & 336 & - & - & - \\
\hline TOTAL & $\mathbf{2 4 2}$ & $\mathbf{7 2 6}$ & $\mathbf{1 2 1}$ & $\mathbf{3 6 3}$ & $\mathbf{1 0 0 \%}$ \\
\hline
\end{tabular}

\subsection{Model Specification}

The ordinary least squares (OLS) regression model is used as the method of data analysis. Regression is the most suitable tool for use in studying relations between variables. The ordinary least squares (OLS) regression is preferred because it helps in explaining the relationships among the various variables of the study and it brings out the differences that exist between companies, hence making it superior for the analysis required in this article. Thus, the ordinary least squares regression (OLS) will employ to investigate the association between external audit fees and corporate governance in Jordan. Both table (1) and (2) indicted independent and controls variables identification. The form of the fee regression model with the anticipated sign of the coefficients is as follows:

$$
\begin{aligned}
& F E E S=B 0+B 1 \text { BOIND + B2 BOEXP + B3 BOS + B4 ACIND + B5 ACEXP + B6 ACMEET + B7 lnASST + B8 } \\
& R A T I O+B 9 F R+B 10 L E V+B 11 I N D+B 12 R O A+B 13 \text { BIGFOUR }+e
\end{aligned}
$$


Table 2. Independent variables identification

\begin{tabular}{|c|c|c|}
\hline Independent variables & Code & Measurement \\
\hline Board Independence & BOIND & It is measured as the ratio of percentage of outside directors / total directors. \\
\hline Board Expertise & BOEXP & $\begin{array}{l}\text { It is a dummy variable takes the value (1) if the board of company contains at least } \\
\text { one member with financial or accounting expertise, and (0) otherwise. }\end{array}$ \\
\hline Board Size & BOS & It is a total of board members. \\
\hline Audit Committee Independence & ACIND & $\begin{array}{l}\text { Dummy variable takes the value (1) if the audit committee is } 100 \text { percent } \\
\text { independent, (0) otherwise. }\end{array}$ \\
\hline Audit Committee Expertise & ACEXP & $\begin{array}{l}\text { Dummy variable takes the value (1) if the audit committee has a member with } \\
\text { accounting or financial expertise, } 0 \text { otherwise. }\end{array}$ \\
\hline Audit Committee Meeting & ACMEET & The number of meetings of audit committee per year. \\
\hline
\end{tabular}

Table 3. Control variables identification

\begin{tabular}{lcl}
\hline Control variables & Code & \multicolumn{1}{c}{ Measurement } \\
\hline Company Size & LnASST & Natural log of sample company's total assets. \\
Complexity & RATIO & Sum of inventory and accounts receivable divided total asset. \\
Financial Risk & FR & Equity divided total assets. \\
Company Leverage & LEV & Sum of short-term debt and long-term debt /total assets. \\
Type of Industry & IND & Dummy variable: $1=$ manufacturing firm; $0=$ non- manufacturing firm. \\
Profitability & ROA & Return on assets; \\
Auditor Size & BIGFOUR & Dummy variable having value of 1 if the auditor belongs to the Big-four, and 0 otherwise. \\
\hline
\end{tabular}

\section{Results}

\subsection{Descriptive Statistics}

According to sample size, the primary sample size was (121) companies which listed on ASE and meet the selection standards and have the appropriate financial data obtainable, but the researcher have found that there are (9) companies considered as outliers, needed to be excluded because they provided data that causes outliers. Additional analysis of these outliers caused in the fact that (7) companies of them experienced large incidental losses due to impairments of write-offs, other (2) companies reported high level of audit fees because they did not disclose audit fees clearly and separately as other companies, they disclosed audit fees with other fees, the researcher tried to contact with both of them in order to obtain the clear number of audit fees, but no response has been received, therefore the researcher excluded those companies from the sample size. However, a sample of 112 companies (121 primary sample - 9 companies consider as outliers) is sufficient to predict large effects and thus legitimizes the size of sample in this thesis. Tables (4) and (5) show summary statistics (mean, standard deviation, minimum and maximum) for all variables which used in the article.

Table 4. Descriptive statistics of the dependent and independent variables

\begin{tabular}{cccccc}
\hline Variable & Mean & N & St.Dev & Min & Max \\
\hline FEES & 4660 & 336 & 5890 & 875 & 25600 \\
BOIND & 0.319 & 336 & 0.253 & 0.000 & 0.863 \\
BOEXP & 0.582 & 336 & 0.196 & 0.000 & 1.000 \\
BOS & 8.584 & 336 & 2.123 & 5.000 & 14.000 \\
ACIND & 0.462 & 336 & 0.494 & 0.000 & 1.000 \\
ACEXP & 0.434 & 336 & 0.262 & 0.000 & 1.000 \\
ACMEET & 4.321 & 336 & 0.514 & 4.000 & 6.000 \\
\hline
\end{tabular}


Table (4) shows that in Jordan board independence ranges from $0 \%$ to $86 \%$ with an average of $31.9 \%$ and $58 \%$ of the members of board directors of study sample have financial expertise. It was also found that members in some listed companies do not have any financial expertise. In the meanwhile, all members in several other companies have that experience. Based on that, it can be concluded that greatest part of the Jordanian listed firms follow to the guidelines of corporate governance with respect to the financial expertise which indicated that the member of the board of directors should be qualified and enjoys adequate knowledge and experience in finance and administrative affairs. Moreover, table (4) exhibits the average number of board size is nine members.

Table 5. Descriptive statistics of the control variables

\begin{tabular}{|c|c|c|c|c|c|}
\hline Variable & Mean & $\mathbf{N}$ & St.Dev & Min & Max \\
\hline $\operatorname{lnASST}$ & 42.225 & 336 & 1.875 & 21.335 & 63.552 \\
\hline RATIO & 0.283 & 336 & 0.212 & 0.000 & 1.000 \\
\hline FR & 0.542 & 336 & 0.186 & 0.012 & 0.912 \\
\hline LEV & 34.905 & 336 & 34.913 & 0.312 & 247.601 \\
\hline IND & 0.564 & 336 & 0.503 & 0.000 & 1.000 \\
\hline ROA & 0.158 & 336 & 0.231 & -0.168 & 0.483 \\
\hline BIGFOUR & 0.371 & 336 & 0.498 & 0.000 & 1.000 \\
\hline
\end{tabular}

On the other hand, the maximum number of board size is fourteen members, which suggests that some Jordanian firms doesn't adhere the code of Jordanian corporate governance which mentions that the board size should be small enough (minimum 5) for effective decision-making and big enough (maximum 13) for directors to contribute their broad expertise and knowledge appropriately. Table (4) also shows that around 46\% of the Jordanian listed companies have audit committee members who are independent. Furthermore, it was found that $43 \%$ of the members of the audit committee have financial expertise. It was also observed that the audit committees of the study sample meet around four times per year on average. The maximum number of meetings for the companies was six times per year, and the minimum was four times per year.

\subsection{Correlation among Independent Variables}

Correlation analysis is considered as a preliminary test to measure the association between the variables and their strength of the relationship. Correlation coefficients (the Pearson product-moment correlation) offer a numerical summary of the strength and direction of the linear association between two variables. The association between variables can be inspected visually by generating a scatter plot. Moreover, the correlation coefficient (the Pearson) offers an indication of the linear association between variables. Table (6) presents the correlation values between the variables of the study over three year (2010, 2011 and 2012). The diagonal cells having value 1 represents the correlation between variables themselves.

Table (6) indicates that the external audit fees has strong correlation with board independence (BOIND) of (0.187) and is significant at the $1 \%$ level, board expertise (BOEXP) is positively correlated with external audit fees of (0.091) and significant at the 5\%, and the correlation between board size (BOS) and audit fees is significant at the $1 \%$ with correlation coefficient of $(0.168)$. The correlation between audit committee independence (ACIND) and audit fees is positive with coefficient of $(0.144)$ at the $1 \%$ significance level. On the other side, audit committee experience (ACEXP) is positively correlated with audit fees and significant at 5\% level with correlation coefficient of (0.087). On the contrary, audit committee (ACMEET) is insignificant correlated with the level of audit fees.

\subsection{Multivariate Analysis}

The ordinary least squares (OLS) regression model is used as the method of data analysis. The model is similar to the cross-sectional audit fees regression model used by Simunic (1980). The audit fees model is estimated for four times that is for 2010, 2011, and 2012 then for the three years al-together. The results of all these models are almost quantitatively similar to each other. The results of the year's analysis are presented in Table (7). For current research the values of $\mathrm{R}$ squared are almost close to each other and consistently move around $71 \%$ to $75 \%$. The adjusted R-squared improved approximately from $68 \%$ in 2011 to $71 \%$ in 2012 . However, the year 2012 seems to produce a better explanatory model compared to 2010 and 2011.

One could draw the conclusion that, we can depend in the last model whereas includes the whole years (2010, 
2011 and 2012). Moreover, this model is significant with F-statistic value of (39.093) and $p=0.000$, suggesting that the model is statistically valid. The R-squared for this model is $(0.731)$ which means that $73.10 \%$ of the variance in audit fees is explained by the model. The adjusted R-squared is $(0.701)$, which means that $70.10 \%$ of the variance would be explained by the model if it had been a sample of the whole population. Based on that, the present study will test the hypothesis according to the last model which includes the whole years $(2010,2011$ and 2012). The whole year's model is:

$F E E S=7.124+0.088$ BOIND +0.067 BOEXP $+0.105 B O S+0.091$ ACIND + 0.027 ACEXP + 0.032 ACMEET +0.564 LnASST + 0.283 RATIO $-0.089 F R+0.118 L E V+0.082 I N D+0.107 R O A+0.223$ BIGFOUR + e

Table 6. Correlation statistics for variables used in the analyses

\begin{tabular}{|c|c|c|c|c|c|c|c|c|c|c|c|c|c|}
\hline Variables & FEE & BOIND & BOEXP & BOS & ACIND & ACEXP & ACMEET & InASST & RATIO & FR & LEV & ROA & BIG44 \\
\hline FEE & 1 & & & & & & & & & & & & \\
\hline BOIND & $.187^{* * *}$ & 1 & & & & & & & & & & & \\
\hline ВОЕXР & $.091^{*}$ & $.176^{* * *}$ & 1 & & & & & & & & & & \\
\hline BOS & $.168^{* * *}$ & $.435^{* * *}$ & $-.142^{*}$ & 1 & & & & & & & & & \\
\hline ACIND & $.144 * *$ & .082 & .047 & $-.132^{*}$ & 1 & & & & & & & & \\
\hline ACEXP & $.087^{*}$ & $.134^{*}$ & .071 & $-.161^{*}$ & $.154 * *$ & 1 & & & & & & & \\
\hline ACMEET & .036 & .012 & .051 & $-.142^{*}$ & -.021 & .076 & 1 & & & & & & \\
\hline InASST & $.663^{* *}$ & $.164 * *$ & .022 & $.293^{* *}$ & .023 & $-.221 * *$ & .014 & 1 & & & & & \\
\hline RATIO & $.343 * *$ & $.122^{*}$ & -.024 & $.176^{* *}$ & $.132^{*}$ & -.021 & .081 & $.192^{* * *}$ & 1 & & & & \\
\hline FR & $-.118^{*}$ & $.128^{*}$ & .052 & -.134 & -.052 & .084 & .021 & $-.141^{*}$ & $-.223^{* *}$ & 1 & & & \\
\hline LEV & $.168 * *$ & .064 & $.179^{* *}$ & $.196^{* *}$ & .027 & $-.164 * *$ & $.097^{*}$ & $.325^{* * *}$ & -.071 & $.352 * *$ & 1 & & \\
\hline IND & $.132^{*}$ & $.145^{*}$ & $.126^{*}$ & $.274 * *$ & $.152^{*}$ & .121 & .005 & $.133^{*}$ & $.213^{* *}$ & $.216^{* *}$ & $.195 * *$ & & \\
\hline ROA & $.147^{*}$ & -.063 & .082 & .018 & $-.124 *$ & .015 & -.096 & $.319^{* * *}$ & .019 & $.123^{*}$ & .023 & 1 & \\
\hline BIGFOUR & $.275^{* * *}$ & $.121^{*}$ & $.136^{*}$ & $.128^{*}$ & $.112^{*}$ & .091 & $.122^{*}$ & $.134^{*}$ & .091 & $.164 * *$ & $.217^{* *}$ & .052 & 1 \\
\hline
\end{tabular}

The sample is based on observations of 112 firms over the 2010-2012 period.2. Note: **indicates significant at $1 \%$ level; * indicates significance at $5 \%$ level (two-tailed).

\subsection{Analysis of the Results}

Consistent with the first hypothesis, the result indicates that there is a positive and significant association (co-efficient $=0.088$ and $\mathrm{p}<0.05$ ) between board independence and external audit fees. This finding goes in the same line with the prior studies (Bearsly \& Petroni 2001; O'Sullivan 2000; Hay \& Knechel, 2004) and supports "demand side" arguments which suggests such positive association. The investigation into relationship between board expertise and audit fees is the second of study objectives. The positively signed coefficient $(\beta=0.067, \mathrm{p}<$ 0.10) on BOEXP supports the study's hypothesis. This finding goes in the same line with the Carcello et al. (2002) and also it improves demand arguments. This finding suggests that the members of boards of directors who have more experience are more likely to demand high-quality audit work, which leads to higher audit fees. However, the result is different from some previous studies which conducted that board members who have financial expertise enhance the quality of oversight by the board. This enhanced oversight may substitute increased auditor effort and reduce the auditor's assessment of control risk, resulting in decreased audit fees. The study points out that board size is positively and significantly associated with audit fees, the positively signed coefficient $(\beta=0.105, \mathrm{p}<0.05)$. The result indicates that as the board size increases, the probability of financial statement frauds also increases, and the likelihood that the auditors will face litigation risk will be higher, thus the auditors will charge more fees.

The investigation into association between audit committee independence and external audit fees is the fourth of study objectives. The positively signed coefficient $(\beta=0.091, \mathrm{p}<0.10)$ on ACIND supports this hypothesis. This proposes that an independent audit committee director requires higher level of audit assurance and possibly provide stronger support for external auditors throughout their negotiations with management. This ultimately may result in higher audit fees. 
Table 7. Multiple regression result for 2010, 2011, 2012 and the whole years (year-wise)

\begin{tabular}{|c|c|c|c|c|c|c|c|c|}
\hline \multirow[t]{2}{*}{ Variable } & \multicolumn{2}{|c|}{2010} & \multicolumn{2}{|c|}{2011} & \multicolumn{2}{|c|}{2012} & \multicolumn{2}{|c|}{ Whole years } \\
\hline & Coeff & p-value & Coeff. & p-value & Coeff. & p-value & Coeff. & p-value \\
\hline Intercept & 7.142 & 0.000 & 6.089 & 0.000 & 5.245 & 0.000 & 7.124 & 0.000 \\
\hline \multicolumn{9}{|c|}{ Board characteristics. } \\
\hline BOIND & 0.101 & $0.038^{* *}$ & 0.077 & $0.067^{*}$ & 0.095 & $0.054^{*}$ & 0.088 & $0.043^{* *}$ \\
\hline BOEXP & 0.059 & $0.042 * *$ & 0.044 & $0.084 *$ & 0.032 & $0.063^{*}$ & 0.067 & $0.077^{*}$ \\
\hline BOS & 0.137 & $0.027 * *$ & 0.118 & $0.031 * *$ & 0.094 & $0.045^{* *}$ & 0.105 & $0.033 * *$ \\
\hline \multicolumn{9}{|c|}{ Audit committee characteristics } \\
\hline ACIND & 0.082 & $0.053^{*}$ & 0.096 & $0.046^{* *}$ & 0.076 & $0.079^{*}$ & 0.091 & $0.052^{*}$ \\
\hline ACEXP & 0.046 & 0.232 & 0.021 & 0.341 & 0.051 & 0.106 & 0.027 & 0.265 \\
\hline ACMEET & 0.012 & 0.575 & 0.022 & 0.602 & 0.027 & 0.618 & 0.032 & 0.652 \\
\hline \multicolumn{9}{|c|}{ Control variables. } \\
\hline $\ln \mathrm{ASST}$ & 0.496 & $0.000 * * *$ & 0.554 & $0.000^{* * *}$ & 0.432 & $0.000^{* * *}$ & 0.564 & $0.000^{* * *}$ \\
\hline RATIO & 0.296 & $0.032 * *$ & 0.276 & $0.057^{*}$ & 0.303 & $0.022 * *$ & 0.283 & $0.042 * *$ \\
\hline FR & -0.078 & $0.078^{*}$ & -0.108 & $0.039^{* *}$ & -0.098 & $0.043^{* *}$ & -0.089 & $0.069^{*}$ \\
\hline LEV & 0.142 & $0.021 * *$ & 0.087 & $0.056^{*}$ & 0.122 & $0.032 * *$ & 0.118 & $0.042 * *$ \\
\hline IND & 0.098 & $0.076^{*}$ & 0.076 & $0.075^{*}$ & 0.106 & $0.048^{*}$ & 0.082 & $0.067 *$ \\
\hline ROA & 0.106 & $0.044 *$ & 0.116 & $0.031^{* *}$ & 0.079 & $0.085^{*}$ & 0.107 & $0.047^{* *}$ \\
\hline BIGFOUR & 0.233 & $0.012 * *$ & 0.213 & $0.002^{* *}$ & 0.245 & $0.006 * * *$ & 0.223 & $0.008^{* * *}$ \\
\hline F-statistic & 16.125 & & 14.114 & & 17.157 & & 39.093 & \\
\hline Sig.F & 0.000 & & 0.000 & & 0.000 & & 0.000 & \\
\hline R-squared & 0.726 & & 0.711 & & 0.756 & & 0.731 & \\
\hline Adjusted $\mathrm{R}^{2}$ & 0.686 & & 0.682 & & 0.712 & & 0.701 & \\
\hline
\end{tabular}

***indicates significance at $1 \%$ level; ** indicates significance at $5 \%$ level and * indicates significance at $10 \%$ level. The reported p-values are all tow-tailed. All variables are defined in previous sections.

The insignificantly positive co-efficient of the number of audit committee members who have financial or accounting expertise does not support the study hypothesis about the relationship between audit committee expertise and audit fees. Nevertheless, the result of this paper is different from that of some studies showed that audit committee members who have financial experience offer additional support for auditors when negotiating or discussing auditing matters or auditing scope with management. Such skillfulness allow audit committee members to better understand the auditing issues, risks, and the audit processes and procedures offered to address these issues and risks. Thus leading to decrease audit risk (DeZoort \& Salterio, 2001). In-consistent with the study's expectation, the co-efficient of ACMEET is insignificant. This result goes in the same line with the finding of previous research which tests the impact of number of meeting on audit quality in Jordan, and confirmed that there is no influence for the number of meetings on the audit quality (Hamdan \& Mushtaha, 2011).

\subsection{Sensitivity Tests}

Prior literatures (e.g., Simon, 1985) suggest use of sensitivity tests in order to ensure the robustness of the proposed audit fees model and the validity of study results. Thus, current study estimates proposed model by using alternative test variable definitions especially the independent variables that showed weak association with audit fees. The primary results indicated that both audit committee experience (ACEXP) and the number of audit committee meetings (ACMEET) did not display any sign of significance for the association with audit fees, and for audit committee independence (ACIND) it has relationship with audit fees, but it is significant at $10 \%$. One possible conjecture concerning this result consistent with notion that the current study did not choose appropriate scale, thus the researcher used continuous versions of audit committee expertise, audit committee meeting and Independent audit committee members to re-estimate the proposed model.

Firstly, for audit committee expertise, the primary model measured this variable as dummy variable, code 
ACEXP as (1) If the audit committee has member with accounting or financial experience (0) otherwise, thus audit committee expertise is defined as the number of audit committee members with financial and accounting knowledge and expertise to the total number of audit committee numbers. Secondly, for audit committee meeting, the primary model used the number of audit committee meetings to test the effect of this variable on audit fees, but the results indicated that there is an insignificant relationship, thus the audit committee meeting measured as dummy variable, code (1) if the audit committee met four times or more per year, (0) otherwise (Abbott et al., 2003). Finally, for audit committee independence, the regression results indicated significant association with external audit fees but it was at $10 \%$, the primary model measured this variable as dummy variable, Code ACIND as (1) if the audit committee is 100 percentage Independent, (0) otherwise, for alternative scale, the audit committee independence measured as the percentage of outsiders on the audit committee (Abbott et al., 2003).

Moreover, the current study used the natural logarithm of total assets at the end of the year to measure the company size. Suggested by some authors (e.g. Simunic, 1980) the control variable to measure auditee size can also by the number of employees instead of total assets. Moreover, it worth pointing out that, several variables used in the regression analysis are correlated with company size measured by the natural logarithm of total assets. In additional regressions, the current study replaced the natural log of total assets (LNASST) by the number of employees (EMPON). Current study undertakes the following sensitivity analyses to check and test whether the study's key results are driven by size effects.

As we can see in this case and through the table (8), where the current study used continuous versions of some independent variables which related to the audit committee characteristics and used the number of employees to measure the firm's size instead of natural log of total asset, the R-square is lower compared to the regression with the natural $\log$ of total assets. However, with an R-square of (0.687), the regression is still very significant. The variable number of employees (EMPON) is positively and strongly significant at $10 \%$. It is remarkable that both of audit committee expertise and audit committee meeting are still not significantly connected with audit fees in spite of using alternative scales. Finally, for board characteristics the results are largely consistent with the main result. One could draw the conclusion that, in all cases, the results were qualitatively unchanged.

Table 8. Sensitivity analysis

\begin{tabular}{|c|c|c|}
\hline \multirow[t]{2}{*}{ Variable } & \multicolumn{2}{|c|}{ Whole years } \\
\hline & Coeff. & p-value \\
\hline Intercept & 7.207 & 0.000 \\
\hline \multicolumn{3}{|c|}{ Board characteristics. } \\
\hline BOIND & 0.092 & $0.027 * *$ \\
\hline BOEXP & 0.078 & $0.056^{*}$ \\
\hline BOS & 0.106 & $0.022 * *$ \\
\hline \multicolumn{3}{|c|}{ Audit committee characteristics } \\
\hline ACIND & 0.096 & $0.023 * *$ \\
\hline ACEXP & 0.011 & 0.572 \\
\hline ACMEET & 0.057 & 0.362 \\
\hline \multicolumn{3}{|l|}{ Control variables. } \\
\hline EMPON & 0.042 & $0.056^{*}$ \\
\hline RATIO & 0.266 & $0.018 * *$ \\
\hline FR & -0.107 & $0.037 * *$ \\
\hline LEV & 0.104 & $0.021 * *$ \\
\hline IND & 0.121 & $0.032 * *$ \\
\hline ROA & 0.134 & $0.021 * *$ \\
\hline BIG4 & 0.231 & $0.005^{* * * *}$ \\
\hline F-statistic & 27.179 & \\
\hline Sig.F & 0.000 & \\
\hline R-squared & 0.687 & \\
\hline Adjusted R-squared & 0.662 & \\
\hline
\end{tabular}




\section{Conclusion and Recommendations}

Using the sample of 112 non-financial companies which listed on (ASE) and meet the selection standards and have the appropriate financial data obtainable from 2010 until 2012, the current study studied the relationship between various features of board of director, audit committee and audit fees in Jordan. The ordinary least squares (OLS) regression model is used as the method of data analysis. It has been chosen because of its advantages. Furthermore, this approach helps in explaining the relationships among the various variables of the study. The outcomes of the current research provide an important insight into the association between external audit fees and corporate governance from an emerging economy like Jordan and the results were as following:

Firstly, consistent with previous research (e.g., O'Sullivan, 2000; Bearsly \& Petroni, 2001; Hay \& Knechel, 2004) the current study observed positive and significant association between external audit fees level and board independence, and this finding supports the "demand side" argument. And this finding seems logical especially in Jordan where new regulatory requirements have increased the legal responsibility of directors. Furthermore, the significant positive results which appeared in this study between audit fees and board size, its consistent with signalling theory which argues that company with high number of boards may follow a strategy of demanding high-quality, adequate audit coverage to make a positive expression in the minds of the investment community about the financial reporting and audit quality, this leading to higher audit fees. Moreover, for board expertise, the result reflected also positive association with external audit fees.

Secondly, surprisingly and contrary to the study arguments, both audit committee expertise and the number of audit committee meetings did not show any significant association with the level of external audit fees. These finding are inconsistent with prior studies (e.g., Abbott et al., 2000; Goddard \& Masters, 2000; Carcello et al., 2002; Abbott et al., 2003). There is a possibility that the absence of such relationship between audit fees and audit committee expertise and the number of audit meeting for the reason that the board characteristics are comprised as Carcello et al. (2002) had argued. They suggested that the findings are consistent with board of directors requiring a higher audit quality to protect their own interests. On the contrary to that, audit committee independence is significantly positively connected with the level of external audit fees, and this goes in line with the study hypothesis which recommended that independent audit committee will demand doing additional audit procedures and supports the auditor while negotiations with the managements, which results in higher audit fees. Moreover, the current study used sensitivity tests to verify the results and to provide additional support for the main findings of this article and are conducted as ways to mitigate the problems of endogeneity that can bias the interpretation of the results of the main article. This test estimated proposed model by using alternative test variable definitions. However, the results which obtained by these analyses are similar to ones reported for the main analyses.

This study is bound by several limitations. Firstly, the measures used in the current study are only proxies for various constructs. The researcher recognizes that corporate governance variables which are used in this research might do not capture the actual monitoring processes taking place within the company. For instance, this study uses dummy variable takes the value (1) if the board of company contains at least one member with financial expertise, and (0) otherwise. The Second limitation is that the definition of financial expertise is maybe too broad and comprises skills that may not certainly contribute to the effectiveness of board director or audit committee. Thus, future research may classify the current definition of accounting and financial expertise into more specific types of expertise, and then investigate their association with audit fees (Krishnan \& Visvanathan, 2009). Thirdly, the measures used in this study are just proxies for various constructs. For example, the audit committee frequency meeting variable is not able to determine the meetings quality. Additionally, it does not capture other forms of communications between the directors and external monitors such as auditors and the regulators and between the audit committee members. Studying these processes requires a case study or qualitative research methods which we leave to future research.

The boundaries of this study open opportunities for future studies. Firstly, future research can conduct comparative study of Jordan with other developing or developed countries. This kind of studies will be useful to see the influence of institutional setting on the level of audit fees. Moreover, these studies will be helpful in explanation how diverse regulatory requirement affect the level of audit fees in different institutional setting. Secondly, financial companies are excluded from this research due to more highly regulatory environment applicable to this sector. Further research using a sample from this sector can be carried out to find out whether there is consistency with regard to the association between audit fees and corporate governance. Finally, as the corporate governance mosaic indicated, there are other external and internal actors in the governance network. The current study only comprised board director and audit committee as the main interests of this study. However, there are several actors in the governance network (e.g. internal audit) may also be interesting for 
future research to study.

\section{References}

Abbott, L., \& Parker, S. (2000). Auditor Selection and Audit Committee Characteristics. Auditing. A Journal of Practice \& Theory, 19(fall), 47-66. http://dx.doi.org/10.2308/aud.2000.19.2.47

Abbott, L., Parker, S., \& Peters, G. (2004). Audit committee characteristics and restatements. Auditing: A Journal of Practice and Theory, 23(1), 69-78. http://dx.doi.org/10.2308/aud.2004.23.1.69

Abbott, L., Parker, S., Peters, G., \& Raghunandan, K. (2003). The association between audit committee characteristics and audit fees. Auditing: A Journal of Practice and Theory, 22(2), 17-32. http://dx.doi.org/10.2308/aud.2003.22.2.17

Abdullatif, M. (2013). Fraud risk factors and audit programme modifications: Evidence from Jordan. Australasian Accounting, Business and Finance Journal, 7(1), 59-77. http://dx.doi.org/10.14453/aabfj.v8i3.2

Abdullatif, M., \& Al-Khadash, H. (2010). Putting audit approaches in context: The case of business risk audits in Jordan. International Journal of Auditing, 14(1), 1-24. http://dx.doi.org/10.1111/j.1099-1123.2009.00400.x

Agrawal, A., \& Chadha, S. (2005). Corporate Governance and Accounting Scandals. Journal of Law and Economics, 48(2), 371-406. http://dx.doi.org/10.1086/430808

Al-Basheer, M. (2003). Corporate Governance and Auditor. Jordan Association of Certified Public Accountants. Proceedings of 5th professional conference (pp. 24-25), Amman. September 2003.

AL-Farah, A. (2001). The Effectiveness of Audit Committees in the Jordanian Public Shareholding Companies: Empirical Study. Unpublished master's thesis, Jordanian university, Jordan.

Alshareef, E. (2008). Corporate Governance and Earnings Management. Unpublished doctoral thesis, University of Arab Academy, Jordan.

Alzoubi, E., \& Mohamad, S. (2012). The Effectiveness of Corporate Governance Mechanisms on Constraining Earning Management Literature Review and Proposed Framework. International Journal of Global Business, 5(1), 17-35.

Beasley, M. (1996). An empirical analysis of the relation between the board of director composition and financial statement fraud. The Accounting Review, 71(4), 443-465.

Beasley, S., \& Petroni, K. (2001). Board independence and audit firm type. Auditing: A Journal of Practice \& Theory, 20, 97-114. http://dx.doi.org/10.2308/aud.2001.20.1.97

Carcello, J., Hermanson, D., Neal, T., \& Riley, R. (2002). Board characteristics and audit fees. Contemporary Accounting Research, 19(3), 365-384. http://dx.doi.org/1506/CHWK-GMQ0-MLKE-K03V

DeZoort, F., \& Salterio, S. (2001). The effects of corporate governance experience, financial-reporting and audit knowledge on audit committee members. Auditing: Journal of Practice and Theory, 20(2), 31-47. http://dx.doi.org/10.2308/aud.2001.20.2.31

Dhaliwal, D., Naiker, V., \& Navissi, F. (2006). Audit Committee Financial Expertise, Corporate Governance, and Accruals Quality: An Empirical Analysis. Working paper, University of Arizona, United States.

Feng, Y., Simon, G., Wanli L., \& Huaili, L. (2012). Determinants of audit committee meeting frequency: evidence from Chinese listed companies. Managerial Auditing Journal, 27(4), 425-444. http://dx.doi.org/10.1108/02686901211218003

Goddard, R., \& Masters, C. (2000). Audit committees, Cadbury Code and audit fees: an empirical analysis of UK companies. Managerial Auditing Journal, 15(7), 358-371. http://dx.doi.org/10.1108/02686900010344638

Griffin, P., Lont, D., \& Sun, Y. (2008). Corporate governance and audit fees: Evidence of countervailing relations. Journal of Contemporary Accounting and Economics, 4(1), 18-49. http://dx.doi.org/10.1016/S1815-5669(10)70028-X

Hamdan, A., \& Mushtaha, S. (2011). The Relationship between Audit Committee Characteristics and Type of Auditor's Report: An Empirical Study on the Public Shareholding Industrial Companies Listed at Amman Bourse. The Arabian Journal of Accounting, 14(1), 109-163.

Hashim, U., \& Rahman, A. (2011). Audit report lag and the effectiveness of audit committee among Malaysian 
listed companies. International Bulletin of Business Administration, 10(2011), 50-61.

Hay, D., Knechel, W., \& Ling, H. (2008). Evidence on the impact of internal control and corporate governance on audit fees. International Journal of Auditing, 12(1), 9-24. http://dx.doi.org/10.1111/j.1099-1123.2008.00367.x

Hay, D., Knechel, W., \& Wong, N. (2004). Audit Fee: A Meta-analysis of The Effect of Supply and Demand Attribute. Working Paper, University of Auckland, New Zealand.

Jenny, S., \& Lois, M. (2007). The Impact of Audit Committee Existence and Audit Committee Meeting Frequency on the External Audit: Perceptions of Australian Auditors. International Journal of Auditing, 11, 51-69. http://dx.doi.org/10.1111/j.1099-1123.2007.00356.x

Khoury, S. (2003). Institutional control and the continuity of institutions, Where does Jordan stand from institutional control? Proceedings of 5th professional conference, Jordan Association of Certified Public Accountants, Amman, 24-25 September.

Krishnan, J., \& Lee J. (2008). Audit committee financial expertise, litigation risk and corporate governance. Auditing: A Journal of Practice \& Theory, 28(1), 241-261. http://dx.doi.org/10.2308/aud.2009.28.1.241

Lajmi, A., \& Gana, M. (2013). Board Characteristics and External Audit Quality: Complementary or Substitute Mechanisms? The Belgium Case. International Journal of Management Sciences and Business Research, 2(3), 68-74.

Lanfranconi C., \& Robertson, D. (2002). Corporate financial reporting: The role of the board of directors. Ivey Business Journal, September/October.

Lisic, L., Neal, T., \& Zhang, Y. (2011). Audit committee financial expertise and restatements: The moderating effect of CEO power. Working Paper, School of Management, George Mason University, United States.

Masoodul, H., Saad, H., Asghar, I., \& Muhammad, F. (2014). Impact of Corporate Governance on Audit Fee: Empirical Evidence from Pakistan. World Applied Sciences Journal, 30(5), 645-651. http://dx.doi.org/10.5829/idosi.wasj.2014.30.05.14093

O'Sullivan, N. (2000). The impact of board composition and ownership on audit quality: evidence from large UK companies. British Accounting Review, 32(4), 397-414. http://dx.doi.org/10.1006/bare.2000.0139

O'Sullivan, N. (1997). Insuring the Agents: The Role of Directors' and Officers' Insurance in Corporate Governance. Journal of Risk and Insurance, 64(3), 545-556. http://dx.doi.org/10.2307/253764

Rutam, S., Rashid, K., \& Zaman, K. (2013). The relationship between audit committee, compensation incentive and corporate audit fees in Pakistan. Economic Modelling, 31(March 2013), 697-716. http://dx.doi.org/10.1016/j.econmod.2013.01.008

Simunic, D. (1980). The pricing of audit services: theory and evidence. Journal of Accounting Research, 18(1), 161-190.

Tsui, J., Jaggi, B., \& Gul, F. (2001). CEO Domination, Growth Opportunities, and their Impact on Audit Fees. Journal of Accounting, Auditing and Finance, 16, 189-207. http://dx.doi.org/10.1177/0148558X0101600303

Wu, X. (2012). Corporate Governance and Audit Fees: Evidence From Companies listed on the Shanghai Stock Exchange. China Journal of Accounting research, 5(2012), 321-342. http://dx.doi.org/10.1016/j.cjar.2012.10.001

Xie, B., Davidson, W., \& DaDalt, P. (2003). Earnings Management and Corporate Governance: The Roles of the Board and the Audit Committee. Journal of Corporate Finance, 9(3), 295-317. http://dx.doi.org/10.1016/S0929-1199(02)00006-8

\section{Copyrights}

Copyright for this article is retained by the author(s), with first publication rights granted to the journal.

This is an open-access article distributed under the terms and conditions of the Creative Commons Attribution license (http://creativecommons.org/licenses/by/3.0/). 